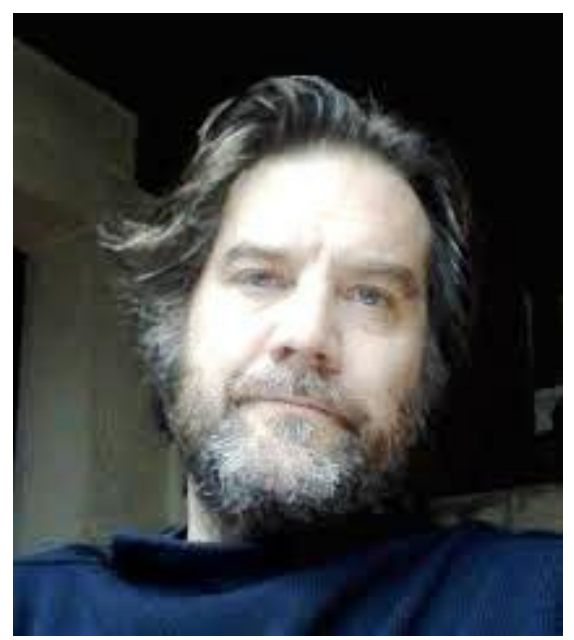

\title{
ENTREVISTA COM O PROF. DR. RÉGIS MISSIRE DA UNIVERSIDADE DE TOULOUSE 2
}

ASEL - Monsieur Missire é uma honra entrevistá-lo nessa ocasião. Para melhor aproveitamento da produção científica do pesquisador, as publicações da ASEL são distribuídas em três seções: artigos científicos inéditos, traduções e entrevista. A finalidade desta última é tornar conhecida a atividade científica do articulista, o laboratório, centro/universidade onde atua para possibilitar um intercâmbio cultural entre interessados em temas comuns e facilitar as relações com possíveis orientadores de pós-doutorado e doutorado. Em vista disso, pediria ao senhor que fizesse uma breve apresentação de sua atuação científico-profissional e do centro ou laboratório onde atua na França.. .

M. MSSIRE - Obrigado pela oportunidade a mim concedida. Sou Maître de Conférences no Departamento de Ciências da Linguagem na Universidade de Toulouse 2-Fr, desde 2011, onde ensino Semântica do texto e Linguística Textual. Minha formação científica foi realizada dentro do laboratório CPFT (Centro Pluridisciplinar de Semiolinguística Textual), fundado por George Maurand em 1975, depois coordenado por Joseph Courtés e Michel Ballabriga, do qual fui responsável entre2013 a 2015. Hoje co-animo com Patrick Mpondo-Dicka, desde 2019, o Seminário Pluridisciplinar Semiótica: textos, sentido que reúne pesquisadores interessados na convicção de que os textos, seus gêneros e os discursos a que pertencem constituem a dimensão fundamental do desenvolvimento do sentido e da sociedade humana. Os trabalhos do Seminário são confederados pela ideia estruturante de que o caráter semiótico e simbólico das 
produções e atividades humanas - ou seja, culturais - não estão reduzidos, apenas, a dimensões cognitivas computacionais e comunicacionais. Neste sentido, os trabalhos do Seminário visam descrever as especificidades destes estratos semióticos simbólicos que jogam como um meio, no seio do qual, se realizam as práticas sociais, situando-se, epistemologicamente, muito mais no prolongamento do projeto saussureano de uma semiologia considerada como "ciência dos signos no seio da vida social" do que "de uma filosofia das formas simbólicas" tal como pode indicar Cassirer. Trata-se, em particular, de dar pleno direito ao fato de que o meio semiótico-simbólico é, ao mesmo tempo, instituinte (porque condiciona parcialmente o exercício e o desenvolvimento das praticas sociais) e instituído (na medida em que esse estrato se concretiza como um aspecto dos produtos destas práticas). Meu trabalho de pesquisa se situa no campo da semântica linguística, mas, particularmente, da semântica interpretativa de François Rastier (1991).

ASEL: O senhor poderia nos citar algum trabalho que usou essas diretrizes?

M. MSSIRE. O artigo, publicado aqui mesmo na Acta numero 2 de 2019, foi desenvolvido nesta direção: a linguagem, paralelamente à possibilidade que ela oferece aos locutores de formular criticas a percepções ante linguísticas e aos traços que conserva estas percepções nas suas regularidades gramaticais, deve, com efeito, ser percebida nos planos do significante e significado. Mais que um cálculo que opera sobre as unidades de formato lógico-gramatical, a construção do sentido é considerado no plano mais fundamental de uma percepção de fundos e de formas semânticas e semióticas diversamente aparelhadas. Trata-se, então, de retrabalhar os princípios de organização do campo perceptivo atualizados pelos psicólogos da Gelstalt, adaptandoos a descrição do significado linguístico. Sobre estas questões, os trabalhos decisivos realizados por P. Cardiot, D.Piotrowiski, V. Rosenthal e Y-M.Visetti, de vinte anos para cá, foram determinantes na orientação de meu trabalho.

ASEL Quais os temas que, particularmente, constituem o seu interesse?

R. MISSIRE. Em um quadro, naturalmente tomado dentro das problematizações do tipo fenomenológico, atualmente, eu me interesso especificamente, pelas questões seguintes:

* A articulação das relações de significação, designação e expressão.

* A reelaboração da noção "pós estruturalista" de significância. 
* A descrição dos percursos interpretativos, tentando aí distinguir e articular os momentos semióticos diversos (icônico, indiciário, simbólico).

* A questão da iconicidade textual, considerada como correlata de um processo de iconização, do qual é necessário detalhar as condições genérico-discursivas.

Aliás, eu me interesso pela epistemologia e historiografia do estruturalismo linguístico e fui coorganizador com Christophe Gérard do I Colóquio Internacional consagrado à obra de Coseriu, em 2007 (Aix em Provence) e que desde então é realizado a cada dois anos.

ASEL O senhor poderia apresentar os títulos de alguns trabalhos que já publicou?

R. MISSIRE. Veja, a seguir, uma seleção de trabalhos que trazem temáticas próximas àquelas evocadas no artigo aqui publicado:

Missire, R., 2020. «Isotopies et fonds sémantiques », in Bondì, A., Piotrowski, D. (Dir.), Le thème perceptif et expressif. Entre linguistique, sémiotique et philosophie, Paris, CNRS éditions. (à paraître).

Missire, R., 2020. «L'articulation sémiotique du sens textuel. Signifiance, signification, désignation, expression », in A. Guillaume, L. Kurts, Faire sens, faire science, ISTE. (à paraître).

Missire, R., 2018. «Unités linguistiques d'une sémantique discursive », Langages, 210, (1), 17-34.

Missire, R., 2018. «Flux psychique, sémiosis langagière et niveaux de l'analyse linguistique », in É. Blestel, C. Fortineau-Brémond \& M. Poirier Marine (dir.), « Le symbole est-il diabolique ? Signifiant/signifié : la duplicité du signe en question », Signifiances (Signifying), vol. 2.

Missire, R., 2018. « Faire sens et avoir un sens - Note sur la signifiance linguistique », Pratiques, 179/180. DOI : 10.4000/pratiques.4830

Missire, R. 2014. «Semiosis textuelle, stratification attentionnelle et déstratification des plans du langage ». In D. Ablali, S. Badir, D. Ducard., éds : Documents, textes, oeuvre. Perspectives sémiotiques. Rennes : Presses Universitaires de Rennes.

Missire, R., 2010. «Unités linguistiques à signifiant discontinu, du morphème au texte - une approche néo-saussurienne ». In J.-P. Bronckart, C. Bota, E. Bulea., éds : Le projet de Ferdinand de Saussure, Genève : Droz, ch. 9, p. 289-312.

Missire, R., 2007. «Rythmes sémantiques et temporalité des parcours interprétatifs ». In M. Ballabriga, P. Mpondo-Dicka., dir : Rythme, Sens et 
textualités, Linguistique, sémiotique du discours, sémantique des textes, rhétorique, stylistique, poétique. Toulouse : Éditions Universitaires du Sud. p. 75-115.

Missire, R., 2005. «Une larme baudelairienne, essai de description morphosémantique de Tristesses de la lune». Champs du signe, concours et recherche, CAPES et Agrégation de Lettres, 20, Toulouse, Éditions Universitaires du Sud, p. 87-114.

ASEL Agradecemos sua participação nesta seção e esperamos contar com sua colaboração em outras ocasiões. 